\title{
EKSISTENSI DELIK ADAT DI LINGKUNGAN MASYARAKAT SENTOLO, KABUPATEN KULONPROGO YOGYAKARTA*
}

\author{
Agus Sudaryanto** $^{* a n}$ Sigid Riyanto ${ }^{* * *}$ \\ Bagian Hukum Adat dan Bagian Hukum Pidana \\ Fakultas Hukum Universitas Gadjah Mada, Yogyakarta \\ Jalan Sosio Yustisia Nomor 1, Bulaksumur, Sleman, D.I. Yogyakarta 55281
}

\begin{abstract}
This research is empirical law research. The collecting data were analyzed by qualitative and presented descriptively. The research can be concluded as follows: reasons for maintaining delict adat law are religious environment, maintaining norms politeness, adat executed as long as no conflict with the written law and the protection of women. Types of sanction are warning in a visit at night, asked to leave the house for interrogation, community sanctions; the reasons of sanction are near the mosque, maintaining delict adat law, neglection of verbal warning, anticipation pregnant before marriage and aruh-aruh culture must be maintained.
\end{abstract}

Keywords: society, delict adat and sanctions.

\section{Intisari}

Jenis penelitian ini adalah yuridis empiris. Data yang terkumpul dianalisis secara kualitatif dan disajikan deskriptif. Kesimpulan riset adalah: Pertama, alasan mempertahankan hukum delik adat karena lingkungan riligius, menjaga norma kesopanan, adat dijalankan asalkan tidak berbenturan dengan peraturan tertulis dan perlindungan perempuan. Kedua, proses penerapan sanksi masyarakat adalah peringatan dalam bertamu di malam hari, diminta keluar rumah untuk diinterogasi, diberi sanksi yang ditentukan musyawarah masyarakat. Ketiga, alasan penjatuhan sanksi pengusiran adalah lingkungan dekat masjid, mempertahankan hukum delik adat, tidak mengindahkan peringatan, pencegahan hamil di luar nikah, perlunya budaya aruharuh (tegur sapa) harus dipertahankan.

Kata Kunci: masyarakat, delik adat dan sanksi.

\section{Pokok Muatan}

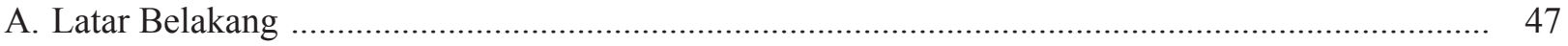

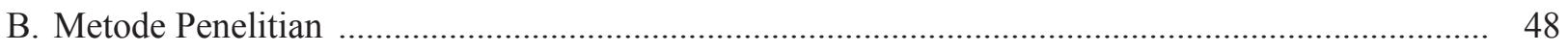

C. Hasil Penelitian dan Pembahasan .................................................................................. 49

1. Alasan Masyarakat Sentolo Kulonprogo Mempertahankan Hukum Delik Adat ...................... 49

2. Penerapan Sanksi Bagi Pelanggar Delik Adat ..................................................................... 52

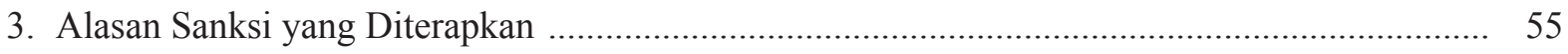

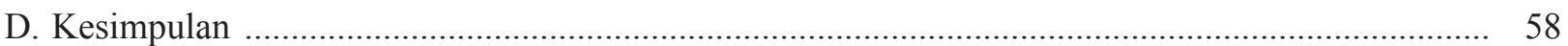

Hasil Penelitian didanai Unit Penelitian dan Pengabdian kepada Masyarakat Fakultas Hukum UGM, 2014.

*** Alamat korespondensi: agus.sudaryanto@mail.ugm.ac.id.

**** Alamat korespondensi: sigid.pid@gmail.com 


\section{A. Latar Belakang}

Soekanto menyatakan dalam hubungannya dengan manusia lain seorang manusia tidak boleh bertindak semau-maunya, dalam kehidupan masyarakat haruslah berpedoman pada norma. Hubungan manusia dengan manusia lain, manusia dengan kelompok maupun hubungan antar kelompok diatur dengan serangkaian nilai-nilai atau kaidah. Kaidah atau norma dalam masyarakat terdiri dari norma agama, kesualiaan, sopan santun dan norma hukum. ${ }^{1}$ Kaidah hukum dapat berwujud peraturan-peraturan tertulis, keputusan-keputusan pengadilan maupun keputusan-keputusan lembaga kemasyarakatan. $^{2}$

Faktanya, hukum tidak bisa dipisahkan dari kehidupan yang nyata, hukum tidak bisa dipandang dari norma-norma hukum yang tertulis saja. Hukum itu bukan hanya dilihat dari sisi legitimasinya saja, bukan hanya bagaimana mengatur sesuai dengan prosedur hukum, melainkan juga bagaimana mengatur sehingga dalam masyarakat timbul berbagai efek yang dikehendaki oleh hukum. Menurut Faisal, perilaku sosial yang terjadi dalam masyarakat yang terjadi dalam peradilan terkadang berjalan dengan benturan-benturan serta ketegangan-ketegangan, hal tersebut disebabkan karena karakteristik perilaku penegak hukum yang beorientasi pada tujuan kepastian hukum yang didasarkan pada pencapaian keadilan prosedural. Orientasi yang demikian itu membuat perilaku penegak hukum tidak mendasarkan diri pada perilaku sosial yang berorientasi pada nilai keadilan yang subtantif. ${ }^{3}$ Keadilan substantif dimaksudkan adalah keadilan yang diciptakan dalam suatu putusan berdasarkan hasil galiannya atas rasa keadilan di dalam masyarakat, tanpa terbelenggu bunyi pasal undang-undang yang berlaku. Keadilan substantif (substantif justice) kerap dilawankan dengan keadilan prosedural (procedural justice), yaitu suatu proses penegakan hukum yang sepenuhnya didasarkan pada bunyi undang-undang. ${ }^{4}$

Negara Indonesia walaupun sudah merdeka sejak tahun 1945, tetapi Wetboek van Strafrecht atau Kitab Undang-undang Hukum Pidana (KUHP) yang berasal dari tiruan Code Penal negara Perancis sampai saat ini masih diberlakukan bagi seluruh rakyat Indonesia. Oleh karena berdasarkan Pasal I Undang-undang No. 73 Tahun 1958 tanggal 20 September 1958 undang-undang ini dinyatakan secara tegas berlaku untuk seluruh wilayah Indonesia. KUHP dengan demikian secara legal dapat dijadikan dasar dalam memutus atau menyelesaikan berbagai masalah yang timbul dalam kehidupan bermasyarakat maupun berbangsa asalkan sudah diatur sebelumnya dengan undangundang. Prinsip harus terlebih dahulu sudah diatur dalam undang-undang sebelum timbul perbuatan ini dikenal dengan asas legalitas. Anselm von Feuerbach asas ini dirumuskan secara komplit dengan kalimat, nulla poena sine lege, nulla poena sine crime, nullum crimen sine poena legali (tidak ada hukuman, kalau tidak ada undang-undang, tidak ada hukuman jka tidak ada kejahatan, tidak ada kejahatan kalau tidak ada hukuman yang berdasarkan atas undang-undang). ${ }^{5}$ Lebih Lanjut dijelaskan oleh Anslem von Feurbach, sebagaimana disampaikan oleh Eddy Hiariej bahwa nulla poena sine lege, nulla poena sine crime, nullum crimen sine poena legali dapat diuraikan menjadi 3 makna, yaitu nulla poena sine lege yang berarti tidak ada pidana tanpa ketentuan pidana menurut undangundang; nulla poena sine crimine yang berarti tidak ada pidana tanpa perbuatan pidana; dan nullum crimen sine poena legali yang berarti tidak ada perbuatan pidana tanpa pidana menurut undangundang. ${ }^{6}$

Bagi bangsa Indonesia sebelum KUHP diberlakukan, tidak dapat dipungkiri sudah ada

\footnotetext{
Soerjono Soekanto,1998, Pokok-Pokok Sosiologi Hukum, Raja Grafindo Persada, Jakarta, hlm. 1-3.

Soerjono Soekanto, Op.cit., hlm. 3.

Faisal, 2009, Menerobos Positivisme Hukum, Rangkang Education, Yogyakarta, hlm.12.

Moh. Mahfud MD, "Keadilan Subtantif”, http://jurnaltoddoppuli.wordpress.com/2014/09/03/keadilan-substantif/, diakses 19 Agustus 2015.

CST Kansil dan Christine ST Kansil, 2007, Pengantar Hukum Indonesia, Sinar Grafika, Jakarta, hlm. 294.

Eddy O.S. Hiariej, 2012, Teori dan Hukum Pembuktian, Erlangga, Surabaya, hlm. 35.
} 
aturan hukum yang tidak tertulis (Hukum Adat) dalam kehidupan masyarakat untuk menjaga ketertiban dan ketentraman. Hukum adat ini tidak bersumber kepada peraturan yang dibuat oleh kekuasaan legislatif sehingga tidak berbentuk undang-undang atau kodifikasi. Menurut Cornelis van Vollenhoven Hukum Adat (termasuk Hukum Delik Adat) ada atau lahirnya melalui cara pandang bangsa Indonesia sendiri, sehingga tidak tergantung kekuasaan negara tetapi berorientasi kepada realitas kehidupan masyarakat saat ini yang disebut ius constitutum bukan yang dianganangan (ius constituendum) dan bukan hukum masa lalu? . Hukum adat itu merupakan hukum yang hidup atau living law sehingga berlakunya tidak terikat peraturan perundang-undangan atau hukum kodifikasi. $^{8}$

Eksistensi hukum delik adat dalam masyarakat saat sekarang nyata masih ada dan dipertahankan oleh masyarakat, seperti belum lama berselang penyidik Kulon Progo melakukan pemeriksaan terhadap 8 orang laki-laki yang bernama SNB, BA,GB, MNA, RA, EY, MRA dan M. Mereka mendatangi rumah Pak RD dan dibukakan NR (korban tewas terlindas kereta api). Kasus yang terjadi di wilayah Sidowayah, Sentolo, Kulonprogo tersebut dilatarbelakangi oleh keberadaan korban di rumah Pak RD yang mempunyai anak gadis bernama AR yang ditengarai punya hubungan khusus (pacar) korban. Oleh para pemuda korban dibawa ke rumah Pak RT untuk dimintai keterangan tentang keberadaan korban di rumah Pak RD. Pemeriksaan yang dilakukan di rumah Pak RT disimpulkan, bahwa korban melanggar norma hukum yang hidup masyarakat, karena menginap di rumah Pak RD tanpa izin ketua RT, korban diminta pulang malam itu dengan jalan kaki yang jaraknya sekitar $10 \mathrm{Km}$. Ketika pulang di pos ronda korban dipukul 2 pemuda yang sekarang menjadi tersangka karena dianggap melanggar pasal 351 ayat (1) KUHP. Pihak keluarga korban melalui LBH Yogyakarta meyakini, bahwa korban meninggal bukan karena tertabrak kereta api tetapi dibunuh, lalu mayatnya ditaruh di rel kereta api.

Kasus tersebut dalam persepektif hukum tertulis (pidana) merupakan tindak pidana. Oleh karena berdasarkan alat bukti yang ada, telah ada saksi yang mengatakan ada pemukulan terhadap korban dan hal itu termasuk tindak pidana penganiayaan. Di samping itu, memaksa pulang malam hari dengan jalan kaki, jaraknya sekitar 10 $\mathrm{km}$ adalah termasuk perbuatan tidak menyenangkan. Penelitian ini pendekatannya bukan mengenai perbuatan pidana, tetapi dalam perspektif hukum delik adat. Kasus pengusiran ini menarik untuk dikaji karena menunjukkan masih kuatnya delik adat dalam kehidupan masyarakat setempat. Indikasinya masih adanya kepedulian warga masyarakat terhadap adanya ketidakharmonisan dalam hidup bersama.

Berdasarkan latarbelakang masalah yang telah diuraikan di atas dapat dirumuskan permasalahan sebagai berikut: Pertama, mengapa warga di lingkungan masyarakat Sentolo Kulonprogo Yogyakarta masih mempertahankan hukum delik adat? Kedua, bagaimana pelaksanaan sanksi delik adat yang diterapkan oleh warga masyarakat Sentolo dalam kasus pengusiran tersebut? Ketiga, apa dasar pertimbangan atas sanksi yang diberikan oleh warga masyarakat Sentolo kepada pelaku pelanggar delik adat?

\section{B. Metode Penelitian}

Penelitian ini merupakan penelitian yuridis sosiologis, yaitu penelitian yang lebih menitikberatkan aspek hukum dalam tataran praktik di masyarakat (law in action). Soemitro, menegaskan bahwa penelitian hukum yang mempergunakan data utama dari data primer atau data yang diperoleh secara langsung dari masyarakat disebut penelitian hukum sosiologis atau empiris. ${ }^{9}$ Di dalam penelitian hukum sosiologis yang berkaitan dengan kasus

Dominikus Rato, 2009, Pengantar Hukum Adat, LaksBang Pressindo, Yogyakarta, hlm. 14-15.

Hilman Hadikusuma, 1992, Pengantar Ilmu Hukum Adat Indonesia, Mandar Maju, Bandung, hlm. 21.

Ronny Hanitijo Soemitro, 1988, Metodologi Penelitian Hukum Dan Jurimetri, Ghalia Indonesia, Jakarta, hlm.10. 
pengusiran yang terjadi di wilayah Sidowayah, Sukoreno, Sentolo, Kulonprogo, Daerah Istimewa Yogyakarta ini diutamakan pengumpulan data langsung dari sumbernya yaitu dari para responden dan nara sumber. ${ }^{10}$ Walaupun demikian, untuk melengkapi data primer dan analisis dilakukan pula penelitian kepustakaan.

Pengumpulan data lapangan, penentuan responden yang dijadikan sampel penelitian didasarkan teknik non-probability sampling khususnya purposive sampling. ${ }^{11}$ Jumlah keseluruhan subyek penelitian sejumlah 14 orang; terdiri dari 8 pemuda yang menerapkan sanksi delik adat, pihak keluarga yang dikenai sanksi sebanyak 3 orang dan sejumlah 3 orang sebagai narasumber. Data yang telah terkumpul dianalisis secara kualitatif dan disajikan secara deskriptif. Analisis kualitatif yang dilakukan menggunakan logika induktif, dimana logika dibangun berdasarkan pada hal-hal khusus atau data di lapangan dan bermuara pada kesimpulan umum. $^{12}$

\section{Hasil Penelitian dan Pembahasan}

1. Alasan Masyarakat Sentolo Kulonprogo Mempertahankan Hukum Delik Adat

\section{a. Masyarakat Agamis}

Berdasarkan penelitian yang dilakukan terkait dengan adanya kasus pengusiran pemuda yang menginap di tempat atau di rumah calon mertua Sentolo Kulonprogo, masyarakat setempat di lokasi kejadian menyatakan secara tegas bahwa, "Masyarakat tempat kejadian walaupun tidak harus disebut dengan masyarakat santri tetapi kegiatan keagamaannya lumayan baik. Apalagi dekat masjid sehingga seharusnya masalah hal-hal yang dilarang oleh agama Islam itu tentunya sudah dipahami oleh warga masyarakat. Lebih lagi keluarga pelanggar delik adat tersebut merupakan penduduk asli, sehingga larangan agama atau adat setempat seharusnya sudah diketahui". ${ }^{13}$

Di lingkungan masyarakat Sentolo di tempat kejadian perkara nampak memiliki lingkungan kehidupan yang agamis sehingga dalam kehidupannya memandang sesuatu masalah tidak dapat dilepaskan dengan hukum agama Islam. Kasus pemuda yang tidur di tempat calon mertua, apapun alasannya menurut perspektif agama Islam merupakan perbuatan yang harus dijauhi. Bagi yang mengetahui suatu perbuatan yang tidak baik yang dilarang agama, maka wajib hukumnya untuk mencegahnya. Ajaran agama Islam menegaskan bahwa barangsiapa yang melihat kemungkaran, hendaklah orang itu mengubahnya dengan tangannya. Apabila tidak mampu dengan tangan, maka mengubahlah kemungkaran itu dengan lisan dan jika tidak mampu dengan lisan, maka dengan hatinya. Mengubah dengan hati artinya hanya diam saja dan jika hanya dengan diam, itu maknanya bahwa orang itu memiliki iman yang paling lemah.

Di dalam perspektif hukum adat, aspek keagamaan atau religius ini merupakan salah satu corak atau cirikhasnya yang sangat fundamental. Cirikhas agamis ini dapat terlihat dalam berbagai upacara, pantangan atau ritus yang dijalankan oleh masyarakat untuk memohon izin dan keselamatan kepada dzat yang dipercaya memiliki kekuatan yang maha kuasa di luar kemampuan manusia.

\section{b. Mempertahankan Norma Kesopan- an \\ Di dalam kehidupan masyarakat} norma atau kaidah kesopanan merupakan norma yang hidup dan timbul dari pergaulan

Maria S.W. Sumardjono, 2007, Metodologi Penelitian Ilmu Hukum, Bahan Ajar Tahun, Fakultas Hukum Universitas Gadjah Mada, Yogyakarta, hlm. 13 .

Burhan Ashshofa, 2001, Metode Penelitian Hukum, Rineka Cipta, Jakarta, hlm. 87-88.

12 Burhan Bungin, 2007, Penelitian Kualitatif Komunikasi, Ekonomi, Kebijakan Publik, dan Ilmu Sosial lainnya, Prenada Media Group, Jakarta, hlm. 143.

13 Hasil wawancara dengan para responden pada tanggal 9 Juni 2014 yang bernama RR, SN, EY, MRA, MNA, BA, ID, dan MW. 
antara warga masyarakat satu dengan warga masyarakat lainnya. Dasar kaedah kesopanan ini adalah kepantasan, kepatutan atau kebiasaan yang berlaku dalam suatu maasyarakat. Pelanggaran terhadap kaedah kesopanan akan dikenakan reaksi atau sanksi oleh masyarakat setempat, yang dapat berupa celaan, cemoohan dan pengucilan pergaulan. ${ }^{14}$

Berkaitan dengan alasan mempertahankan hukum delik adat karena untuk mempertahankan norma kesopanan di lingkungan masyarakat Sentolo, 8 orang responden menyatakan secara tegas sebagai berikut:

Masyarakat di lingkungan tempat kejadian perkara ini sangat menghormati dan menjaga aturan kesopanan yang hidup dalam masyarakat. Jika ada warga masyarakat setempat yang kuwanen, wani nentang (berani melanggar) aturan masyarakat (delik adat), maka masyarakat akan memberikan reaksi atau sanksi. Aturan masyarakat harus dihormati karena yang membuat itu masyarakat sendiri, jika aturan masyarakat tidak dijalankan itu sama artinya melecehkan dirinya sendiri. ${ }^{15}$

Salah satu narasumber masyarakat Sentolo Bapak SO yang menjabat RT setempat, dalam kaitan norma agama dan kesopanan di lingkungan wilayah tempat kejadian perkara menyatakan:

Sepanjang pengetahuannya masalah aturan agama dan sopan santun dalam kehidupan masyarakatnya sudah atau masih cukup kuat dijadikan pegangan dalam aktivitas kemasyarakatan. Kadangkala antara aturan agama dan sopan santun yang timbul dari masyarakat itu sulit dipisahkan. Sebagai contoh dalam kasus pengusiran pemuda yang tidur di tempat calon mertua, yang terjadi pada 15 Oktober 2013 atau malam 10 Dzulhijah $1434 \mathrm{H}$ tersebut, jelas sekali masalah itu dilarang oleh aturan agama dan sopan santun. ${ }^{16}$

Berdasarkan data yang berasal dari hasil wawancara dengan responden dan narasumber tersebut, tampak jelas bahwa norma kesopanan dalam kehidupan masyarakat Sentolo khususnya di wilayah tempat kejadian perkara masih sangat dijunjung tinggi. Apapun alasannya jika ada anggota masyarakat yang tidak menjaga aturan sopan santun, maka masyarakat akan memberikan reaksi secara spontan atas suatu pelanggaran norma tersebut. Di dalam kasus pengusiran ini, walaupun yang berinisiatif berawal dari pihak pemuda tetapi dalam penegakan norma kesopanan di wilayah tempat kejadian perkara kemudian didukung oleh tokoh masyarakat dan ketua RT setempat. Hal tersebut mengindikasikan bahwa seluruh lapisan masyarakat setempat masih sangat menjaga norma sopan santun dalam rangka untuk menjaga peradaban dalam pergaulan bersama.

\section{c. Adat Dijalankan Asalkan Tidak Berbenturan dengan Peraturan Tertulis}

Istilah adat merupakan aturan bangsa Indonesia yang sudah ada sebelum kedatangan bangsa Barat (Eropa). Berbagai istilah yang sudah lama dikenal dalam kehidupan masyarakat Indonesia, seperti odot (Gayo Aceh), hadat (Lampung), ngadat (Jawa), ade (Bugis) dan adati (HalmaheraMaluku). Adapun istilah kebiasaan yang berasal dari bahasa Arab adah artinya sesuatu yang berulang, sehingga dapat berdemensi individual maupun kolektif. Artinya, adat yang bermakna kebiasaan itu

\footnotetext{
Ishaq, 2008, Dasar-Dasar Ilmu Hukum, Sinar Grafika, Jakarta, hlm. 31.

Hasil wawancara dengan para responden pada tanggal 9 Juni 2014 yang bernama RR, SN, EY, MRA, MNA, BA, ID, dan MW.

Hasil wawancara dengan narasumber Bapak SO sebagai Ketua RT tempat kejadian perkara pada tanggal 9 Juni 2014.
} 
harus merupakan kebiasaan yang normatif telah termanisfestasi dalam aturan tingkah laku dalam masyarakat dan dipertahankan oleh masyarakat. ${ }^{17}$ Di samping itu, Van Vollenhoven sebagaimana dikutip oleh Van Dijk menyatakan bahwa adat dan hukum adat selalu bergandeng tangan (beriringan) dan tidak dapat dipisahkan satu dengan lainnya. Kedua istilah tersebut hanya dimungkinkan dibedakan mengenai ada dan tidaknya suatu akibat hukum..$^{18}$

Berkaitan kasus pengusiran yang terjadi di wilayah Sentolo Kulonprogo, menurut salah satu narasumber dinyatakan sebagai berikut:

Adat yang baik dalam kehidupan masyarakat harus dijalankan asalkan tidak berbenturan dengan hukum negara atau hukum tertulis. Hal ini karena dilatarbelakangi adat itu dapat berfungsi untuk melindungi masyarakat yang bersangkutan dan adat apapun yang muncul dalam suatu masyarakat sangat terkait alam pikiran maupun pengalaman hidup yang dialami oleh masyarakat setempat. Adat atau hukum delik adat yang kadang merupakan warisan nenek moyang layak dijalankan tetapi terbatasi oleh sifat lokal dan tidak bertentangan dengan hukum tertulis. ${ }^{19}$

Walaupun dalam faktualnya masyarakat tidak dapat membedakan antara kebiasaan, adat maupun hukum adat tetapi mempunyai pemahaman bahwa melanggar adat (kebiasaan, adat atau hukum adat) itu harus diberikan reaksi yang berasal dari masyarakat setempat. Adat itu berasal dari masyarakat setempat bukan dari pemerintah sehingga yang mempertahankan tentunya juga masyarakat sendiri bukan dibebankan kepada negara.

\section{d. Perlindungan terhadap Perempuan dalam Menjaga Harmoni Kehidupan}

Berdasarkan ajaran agama Islam kedudukan antara lelaki dan perempuan juga dapat dikatakan disetarakan. Hal ini dapat dilihat di dalam Surat An Nahl ayat 97, "Barang siapa yang mengerjakan kebaikan baik laki-laki atau perempuan dalam keadaan beriman, maka Allah akan menghidupkan dalam kehidupan yang baik dan akan diberikan balasan dengan pahala yang lebih baik dari apa yang telah mereka kerjakan". Di dalam perspektif hukum adat, di masyarakat parental seperti yang berlaku di Suku Jawa bentuk perkawinan yang dijalankan adalah perkawinan bebas (Jawa: mentas, mencar). Hal ini membawa konsekuensi dalam hubungan suami isteri mempunyai kedudukan seimbang dalam mengurus kehidupan rumah tangganya. ${ }^{20}$ Hazairin sebagaimana yang dikutip oleh Bushar Muhammad menyatakan sistem kemasyarakatan keibu-bapaan yang menarik garis keturunan melalui ibu dan bapak, mempunyai makna ibu-bapak serta keluarga ibu-bapak sama nilai dan sama derajatnya. ${ }^{21}$ Kesetaraan kedudukan antara lelaki dan perempuan dalam hukum adat Jawa juga ditunjukkan dalam masalah hak waris. Suami dan isteri karena pengaruh yurisprudensi dapat saling waris mewarisi dan anak lelaki atau perempuan pada prinsipnya memiliki kedudukan dan hak yang sama atas harta warisan orangtuanya. ${ }^{22}$

Berkaitan adanya kasus pengusiran yang terjadi pada masyarakat Sentolo Kulonprogo dapat diketahui salah alasan perlunya mempertahan hukum delik adat adalah untuk melindungi pihak perempuan 
dalam kehidupannya. Hal ini dinyatakan oleh responden sebagai berikut:

Di dalam kehidupan masyarakat, aturan yang hidup di masyarakat seharusnya dipatuhi oleh seluruh warga masyarakat setempat. Apabila ada anggota masyarakat yang tidak mematuhi, itu artinya menantang masyarakat. Aturan masyarakat dalam jam bertamu harus ditegakkan karena tidak lepas adanya pengalaman masa lalu di masyarakat setempat. Ketika jam bertamu tidak dijalankan, pernah terjadi tengik atau meteng ndisik (hamil dahulu sebelum nikah). Peristiwa itu dijadikan pelajaran oleh masyarakat setempat, bahwa bertamu yang melewati batas jam itu sangat riskan terhadap perbuatan maksiat. ${ }^{23}$

Berdasarkan data yang berasal dari wawancara di atas, masyarakat di wilayah tempat kejadian perkara sudah memahami bahwakedudukan antaralelakidanperempuan itu dalam kehidupan rumah tangga maupun masyarakat adalah sama. Hal yang perlu disadari bahwa perempuan sebagai manusia mempunyai keterbatasan untuk menanggung risiko yang ditimbulkan dari peristiwa hamil di luar pernikahan. Jika sampai terjadi hamil di luar nikah, maka pihak yang paling dirugikan dan menanggung beban lebih berat dalam pergaulan di masyarakat adalah pihak perempuan. Pengalaman yang lalu adanya hamil di luar nikah tersebut mendorong bagi masyarakat Sentolo untuk terus mempertahankan terhadap eksistensi hukum delik adat agar dipatuhi oleh masyarakat setempat.

2. Penerapan Sanksi Bagi Pelanggar Delik Adat

\section{a. Peringatan Kepada Pelaku dan Ke- luarga}

Berdasarkan informasi salah seorang responden yang bernama $\mathrm{BA}^{24}$ dan dikuatkan oleh 7 responden lainnya serta tokoh masyarakat Bapak BI, bahwa penegakan hukum delik adat terlebih dahulu dilakukan peringatan. Pemuda telah memperingatkan melalui keluarga dan anak perempuan agar tidak mengijinkan menerima tamu laki-laki yang mempunyai hubungan pacar untuk menginap. Selain mengingatkan kepada keluarga, peringatan juga pernah disampaikan kepada NR agar tidak menginap di rumah pacarnya sebelum nikah secara resmi. Selain itu, pemuda juga mengharapkan agar kalau ketemu dengan warga desa mau menegor terlebih dahulu.

Peringatan yang telah disampaikan secara lisan oleh para pemuda di atas, menurut responden sebagaimana disampaikan oleh $\mathrm{MW}^{25}$ tidak diperhatikan. Berdasarkan keterangan Bapak RD orang tua calon mempelai perempuan $(\mathrm{AR})^{26}$, bahwa peringatan tersebut secara langsung belum pernah didengar, namun memang diakui pernah disinggung dalam acara pertemuan warga tentang larangan untuk menerima tamu menginap tanpa ijin. Pak RD menyatakan tahu kalau lelaki yang belum sah sebagai istri tidak baik menginap di tempat perempuan meskipun sebagai calon suami. Pak RD memberikan keterangan, bahwa tidak pernah mengijinkan NR menginap di rumahnya, karena memang tidak ada permintaan ijin, baik oleh NR maupun oleh anaknya sendiri. Pak RD tidak menegor, karena beranggapan mereka sudah calon suami istri, keluarga NR sudah melamar dan waktu kejadian sedang diurus ijin perkawinan dari Pengadilan Agama Wates.

\section{b. Rumah Calon Mertua Didatangi Pemuda}

Kedatangan para pemuda yang

\footnotetext{
Hasil wawancara dengan BA dan didukung oleh tokoh masyarakat atau agama masyarakat setempat yang bernama SI pada tanggal 9 Juni 2014.

Wawancara dengan responden yang bernama BApada tanggal 9 Juni 2014.

Wawancara dengan responden yang bernama MW pada tanggal 9 Juni 2014

Wawancara denganresponden yang bernama Bapak RD pada tanggal 16 Juni 2014
} 
berjumlah sekitar 8 orang sekitar jam 1 malam datang kerumah Pak RD, untuk memastikan keberadaan NR, karena sekitar jam 22:00 atau 10 malam, ada yang melihat NR bersama dengan AR. Pada waktu pintu rumah Pak RD diketuk, yang keluar (membuka pintu) Sdr. NR, para pemuda mengira Pak RD dan keluarga yang lain sudah tidur. Berdasarkan informasi dari keluarga Pak $\mathrm{RD}^{27}$ sebenarnya dia belum tidur, tetapi ibu dan anaknya menerangkan sudah tidur. Pak RD mendengar ada beberapa pemuda yang ketok pintu, tetapi belum sempat keluar NR sudah bangun dan membukakan pintu. Setelah itu diajak pergi oleh para pemuda dan saat itu Pak RD mengira diajak ke masjid untuk takbiran. Kenyataannya, tidak diajak takbiran di masjid tetapi diajak menuju pos ronda dengan tujuan untuk diinterogasi masalah hubungannya dengan calon isterinya.

\section{c. Pelaku Diminta Keluar Rumah}

Berdasarkan kenyataan bahwa NR benar-benar berada dirumah (menginap di tempat Pak RD) bahkan yang membukakan pintu, maka bukti lelaki tersebut tidur di tempat calon mertua sulit terbantahkan. Ketika pemuda sudah membuktikan bahwa ada dugaan lelaki tidur di tempat calon mertua, selanjutnya NR diajak ke luar rumah. Atas inisiatif BA yang dikuatkan oleh responden lain, ${ }^{28}$ bahwa maksud mengajak NR ke luar rumah tersebut untuk diajak ke gardu pos ronda bersama dengan para pemuda setempat. Berkaitan dengan ijin menginap di rumah Pak RD, NR menjawab sudah, namun beberapa pemuda tidak percaya dan mengajak ke rumah Pak SO (Ketua RT) untuk menanyakan apakah sudah benar ada ijin menginap. Setelah sampai rumah Pak SO, NR dipertemukan dan Pak SO menyatakan, bahwa NR tidak pernah minta ijin kepadanya sewaktu menginap di rumah Pak RD. ${ }^{29}$

Menurut Pak RD (calon mertua) sebagai pihak yang memiliki rumah, dengan diajaknya NR (calon mantu) ke luar rumah secara spontan oleh para pemuda tersebut tidak pada tempatnya. Mengajak secara langsung ke luar rumah pihak tamu, tanpa izin pemilik rumah tersebut merupakan tindakan yang kurang baik. Hal ini dikarenakan dapat diartikan pihak pemuda tidak menghormati tuan rumah. Seharusnya jika mengajak NR (tamu) yang berposisi sebagai tamu, maka pertama harus kulo nuwun (memberitahu kedatangan) dulu dengan tuan rumah. Selanjutnya, apabila pihak tamu akan diajak ke luar rumah, maka pihak tuan rumah harus diberitahu tentang masalah, tujuan dan tempatnya. Dengan demikian, selaku tuan rumah harusnya dapat memiliki kejelasan terhadap masalah yang dihadapi dan proses penyelesaiannya. ${ }^{30}$

\section{d. Proses Peradilan Adat}

Hukum adat merupakan hukum yang hidup di tengah-tengah masyakat, bersifat fleksibel sehingga dapat mengikuti kondisi dan perkembangan masyarakat. Gangguan yang terjadi merupakan suatu persoalan yang dapat mengancam kehidupan masyarakat, sebagai responnya dapat berupa tindakan yang dilakukan bersifat kolektif. Pemeriksaan terhadap NR pada prinsipnya dilakukan secara kolektif (para Pemuda) di bawah pengawasan Pak SO sebagai Ketua RT. Pertanyaan berkaitan dengan asal usul, pekerjaan, status perkawinan, kapan mulai mengenal AR, sampai sejauh mana hubungan dilakukan. Pengakuan NR dirasakan sangat mengagetkan para pemuda, karena malam itu memang tidur sekamar dengan AR. Oleh NR

\footnotetext{
Wawancara dengan responden Pak RD, Ibu ND dan AR tanggal 16 Juni 2014

Wawancara dengan responden yang bernama BA pada tanggal 9 Juni 2014.

Wawancara dengan Bapak SO selaku Ketua RT pada tanggal 9 Juni 2014.

Wawancara dengan responden yang bernama Bapak RD sebagai pihak calon mertua, pada tanggal 16 Juni 2014.
} 
diakui bahwa mereka berdua sudah pernah tidur bersama di tempat lain dan seingatnya sudah pernah 2 (dua) kali. Bagi pelaku pelanggaran delik adat, alasan menginap di tempat calon mertua karena sudah menjadi calon suami istri yang sah, orang tuanya sudah melamar dan tinggal menunggu ijin nikah dari Pengadilan Negeri Wates. Selain itu, diakui bahwa kedatangan ke rumah AR (Pak RD) atas kehendak AR (dijemput AR). ${ }^{31}$

Berdasarkan keterangan Pak RD, Bu $\mathrm{RD}(\mathrm{ND})$ dan putrinya yang bernama AR, diperoleh keterangan bahwa kedatangan ke rumah Pak RD, memang diakui dijemput AR, karena hal yang demikian memang sudah biasa dilakukan. Apabila tidak dijemput AR, NR kalau datang ke rumah AR berjalan kaki, naik sepeda atau diantar oleh temannya, karena NR tidak mempunyai sepeda motor sendiri. ${ }^{32}$ Berdasarkan keterangan yang diberikan oleh para pemuda, Ketua RT, calon isteri dan pihak keluarga calon mertua dapat disimpulkan telah terbukti secara meyakinkan bahwa telah terjadi delik adat. Hal ini dikarenakan, ada aturan yang hidup dalam masyarakat setempat (living law), yaitu larangan bertamu melewati batas dan juga tidur bersama sebelum menjadi suami isteri yang sah sudah diabaikan oleh pelaku. Oleh karena itu, dua tahapan proses peradilan, yaitu mengkonstatir dan mengkualifisir terhadap delik adat sudah dapat dilalui.

\section{e. Pemberian Sanksi Masyarakat}

Di dalam menjatuhkan sanksi setelah dilalui tahap mengkonstatir dan mengkualifisir peristiwa, maka baru dapat dilakukan tahap mengkonstituir sehingga dapat menjatuhkan hukuman atau sanksinya. ${ }^{33}$ Berdasarkan pengakuan NR di atas, maka musyawarah pemuda yang diketui oleh Ketua RT memutuskan agar NR pulang ke rumah malam itu juga. Putusan pulang dengan jalan kaki tersebut dimaksudkan agar NR tidak mengulangi perbuatannya. NR diminta kembali ke rumah Pak RD untuk mengambil tas dan baju. Sewaktu datang ke rumah RD, dia hanya pamit pulang dan akan kembali lain waktu kalau persyaratan pernikahan sudah terpenuhi untuk cara ijab qobul. Pak RD tidak mengira kalau malam itu diminta pulang oleh pemuda dengan berjalan kaki. ${ }^{34}$

Mengenai sanksi pengusiran yang telah diputuskan oleh pemuda dan pemuka masyarakat juga tidak tahu persis dari mana sumbernya. Sanksi tersebut hanya didasarkan kata sepakat di antara pemuda dan pemuka masyarakat yang ada dengan pelaku. Berdasarkan pendapat narasumber Pak BI (tokoh masyarakat) menyesalkan kejadian tersebut, meskipun bisa mengerti alasan para pemuda. Menurut Pak BI, ${ }^{35}$ pemuda yang nginap di tempat perempuan adalah merupakan perbuatan yang melanggar nilai agama (Islam). Mestinya malam itu tidak diminta pulang, tetapi cukup diminta tidur di Pos Ronda dengan ditemani para pemuda, atau dirumah penduduk dan Pak BI juga menyediakan kamar, apabila dibawa ke rumahnya.

Senada dengan pendapat tersebut menurut Pak MO, hukum adat adalah satu hukum yang dapat berfungsi untuk menjaga ketenangan, ketenteraman dan harmonisasi dalam kehidupan bermasyarakat. Selain itu, Pak MO juga menyayangkan pengusiran di waktu malam, karena kasihan malam hari sekitar jam 1 malam pulang sendiri, dengan jarak sekitar $10 \mathrm{KM}$, dengan jalan kaki.

\footnotetext{
Hasil wawancara dengan para pemuda selaku responden pada tanggal 9 Juni 2014 yang bernama RR, SN, EY, MRA, MNA, BA, ID, dan MW. Hasil wawancara dengan Bapak RD, Ibu RD (ND) dan anak putrinya AR pada tanggal 16 juni 2014.

Sudikno Mertokusumo, 1982, Hukum Acara Perdata Indonesia, Liberty, Yogyakarta, hlm. 84-85.

Wawancara dengan responden Bapak RD pada tanggal 16 Juni 2014.

Wawancara para narasumber Bapak BI dan MO pada tanggal 9 Juni 2014.
} 
Di dalam kaca hukum formal perbuatan demikian itu saat sekarang bukan merupakan tindak pidana. Sebelum ada putusan Mahkamah Konstitusi (MK) Nomor 1/ PUU-XI Tahun 2013, perbuatan pengusiran adalah merupakan perbuatan yang melanggar Pasal 335 KUHP tentang perbuatan yang tidak menyenangkan. Pasal tersebut telah dicabut, maka perbuatan pengusiran tersebut tidak dilanjutkan dan saat sekarang penyidik sedang fokus melakukan penyidikan atas kematian NR yang terlindas kereta api. ${ }^{36}$

\section{Alasan Sanksi yang Diterapkan}

\section{a. Dekat Masjid}

Sebagai salah satu jamaah masjid tersebut (calon mertua), secara normal tentunya sudah memahami tentang adanya larangan dan batasan pergaulan antara lelaki dan perempuan yang belum berstatus suami isteri. Pihak calon mertua dalam kaitan ini memberikan alasan sebagai berikut, "Bertamu lewat batas waktu seharusnya diperbolehkan asalkan sudah ada lamaran. Jika pihak perempuan sudah menyetujui, maka bertamu melewati batas waktu itu sudah menjadi tanggung jawab pihak keluarga perempuan. ${ }^{37}$

Di sisi lain, pihak masyarakat yang terdiri dari para pemuda, dan tokoh masyarakat setempat, dalam kaitan kasus pengusiran tersebut secara tegas menyatakan sebagai berikut:

Tempat kejadian masalah bertamu melewati batas waktu adalah di dekat masjid dan ditambah lagi saat itu bertepatan dengan tanggal 15 Oktober 2014 atau 9 malam Dzulhijah 1434. Malam itu masyarakat sekitarnya sedang melakukan takbir untuk menyambut Hari Raya Idul Qurban sehingga sangat bertolak belakang dengan aktivitas yang dilakukan oleh pihak pelaku delik adat. Masyarakat pada umumnya saat itu melakukan takbir untuk taqarrubillah (mendekatkan diri pada Allah), sedangkan di pihak lain ada yang melakukan perbuatan maksiat yang melanggar perintah Allah. ${ }^{38}$

Berdasarkan hasil wawancara tersebut, nampak pihak keluarga calon mertua berusaha membela diri agar pelaku tidak pada tempatnya dijatuhi sanksi oleh masyarakat karena sudah melamar anaknya. Pihak perempuan tidak memahami bahwa dalam pergaulan dalam masyarakat itu harus mengakomodasi aspirasi masyarakat setempat. Apabila kehendak masyarakat tidak diakomodasi dalam pergaulan, maka masyarakat akan melakukan perlawanan dengan cara memberikan reaksi. Menurut Ali, suatu kehidupan bersama akan terpelihara dengan baik jika ada unsur kekuatan yang menyertainya dengan kekuatan yang berupa kekuasaan dapat dijadikan sarana untuk mempertahankan ketertiban (orde) masyarakat. ${ }^{39}$ Kelompok pemuda yang didukung tokoh masyarakat merupakan the ruling class dan memiliki kekuasaan (power) sehingga dapat mendominasi atau mempengaruhi suatu keputusan dalam masyarakat. Adanya kekuasaan ditangan, para pemuda dan tokoh masyarakat mendapatkan legitimasi untuk mengembalikan ketertiban yang terganggu.

\section{b. Kepatuhan Warga terhadap Hukum Delik Adat Setempat}

Di dalam kasus pengusiran yang terjadi di masyarakat Sentolo nampak jelas bahwa alasan dijatuhi sanksi bagi pelaku delik adat adalah dikarenakan masyarakat setempat masih harus mentaati aturan hukum yang

Wawancara dengan para nara sumber Bapak BI dan Bapak MO pada tanggal 9 Juni 2014.

Hasil wawancara dengan Bapak RD sebagai calon mertua dan sekaligus orangtua pihak perempuan yang bernama AR pada tanggal 16 Juni 2014.

Hasil wawancara dengan para responden dan tokoh masyarakat setempat yang bernama Bapak BI pada tanggal 9 Juni 2014.

Zainuddin Ali, 2006, Sosiologi Hukum, Sinar Grafika, Jakarta, hlm. 19. 
berasal dari masyarakat yang bersangkutan. Indikasinya sebagaimana dinyatakan oleh salah satu tokoh masyarakat setempat sebagai berikut:

Sudah menjadi pengertian masyarakat setempat bahwa jika bertamu di waktu malam hari dibatasi sampai pukul 22.00 WIB. Lebih-lebih jika pemuda yang bertamu ke rumah pemudi, maka jam tersebut seharusnya dipatuhi. Jika tidak mengindahkan aturan tersebut, artinya orang itu kuwanen karena menantang aturan yang hidup dalam masyarakat. Oleh karena itu, untuk mempertahankan hukum delik adat yang sudah ada supaya tetap dipatuhi, maka sanksi itu diperlukan. ${ }^{40}$

Hukum delik adat khususnya yang berkaitan dengan pembatasan bertamu di malam hari, di lingkungan masyarakat tempat kejadian perkara pengusiran sangat nampak jelas masih dipertahankan oleh masyarakat setempat. Hal ini membuktikan, bahwa hukum delik adat yang berasal dari masyarakat itu eksistensinya sangat tergantung dari masyarakat itu sendiri. Walaupun mungkin dilarang oleh hukum negara, tetapi jika rasa keadilan masyarakat masih menghendaki dipertahankan, maka hukum delik adat tetap akan eksis dalam kehidupan masyarakat. Masalah tersebut tidak dapat dilepaskan karena secara faktual hukum delik adat itu merupakan cerminan atau refleksi dari masyarakat yang bersangkutan. Sebagaimana dinyatakan Cornelis van Vollenhoven semua perbuatan yang bertentangan dengan kepatutan, ketertiban, kesadaran hukum masyarakat dapat dikategorikan sebagai delik adat. Perbuatan pelaku (NR) yang bertamu melewati waktu dan bahkan tidur di tempat calon isteri membuat masyarakat resah atau tidak nyaman sehingga tidak dapat dihindari memunculkan reaksi masyarakat.

\section{c. Tidak Mengindahkan Peringatan}

Sebelum terjadi pengusiran, masyarakat sudah pernah memberi peringatan sampai dua kali sebagaimana dinyatakan resnponden dan didukung oleh Ketua RT setempat sebagai berikut:

Delik adat yang telah dilanggar oleh pelaku yang berasal dari luar wilayah setempat, yaitu Desa Banyurata Kecamatan Nanggulan dengan sanksi berupa pengusiran tersebut tidak serta merta diterapkan. Sebelum diberikan sanksi pengusiran, masyarakat melalui Bapak Rasid Rabangi sudah memperingatkan dua kali agar keluarganya mematuhi aturan yang hidup di masyarakat. Ternyata peringatan pertama tidak dihiraukan dan keduapun juga diabaikan. Akhirnya masyarakat menerapkan sanksi kepada pelaku delik adat. Padahal jika peringatan pertama atau kedua diindahkan, maka masyarakat tidak akan menerapkan sanksi yang berupa pengusiran pelaku dari wilayah kejadian. ${ }^{41}$

Berdasarkan data tersebut terlihat jelas bahwa alasan pemberian sanksi pengusiran dari wilayah tempat kejadian merupakan hasil kompromi antara masyarakat dan pelaku delik adat. Namun penyelesaiannya masalah yang terjadi sudah melibatkan tokoh masyarakat dan Ketua RT. Dalam pemberian sanksi yang berupa pengusiran terhadap pelaku delik adat, tidaklah tiba-tiba tetapi sudah melalui pentahapan, yaitu berupa dua kali peringatan secara lisan.

Dalam penyelesaian masalah ini, secara empirik aturan hukum adat (hukum delik adat) yang digunakan. Oleh karena masyarakat setempat berdasarkan rasa keadilan yang tumbuh, masih berkeyakinan bahwa hukum delik adat masih layak dan memang seharusnya dijalankan dalam

Hasil wawancara dengan tokoh masyarakat setempat yang bernama BI pada tanggal 9 Juni 2013.

41 Hasil wawancara dengan saudara MW, RR dan Bapak SO selaku Ketua RT tempat kejadian perkara pada tanggal 9 Juni 2014 
kehidupan masyarakat setempat. Walaupun tidak dapat dipungkiri selain hukum delik adat, sebenarnya terdapat alternatif hukum lain yang dijadikan norma untuk menyelesaikan masalah dalam masyarakat setempat. Menurut Teori Semi-otonomous Social Field dari Falk Moore seperti yang dikutip oleh Saptomo dinyatakan bahwa dalam satuan sosial, hukum adat dapat digunakan menyelesaikan berbagai masalah hubungan sosial meskipun pada satuan sosial tersebut terdapat aturan yang mengatur hal sama. ${ }^{42}$

\section{d. Pencegahan Hamii di Luar Nikah}

Apabila ada peristiwa hamil di luar nikah dapat dipastikan bahwa sebelumnya pernah terjadi persetubuhan (sexual intercourse) antara dua orang yang berbeda jenis kelaminnya di luar perkawinan atau zina. Walaupun menurut KUHP (Kitab Undangundang Hukum Pidana) tidak setiap pelaku zina diancam dengan hukum pidana, tetapi menurut hukum agama Islam maupun Hukum delik adat di lingkungan masyarakat Jawa termasuk perbuatan yang dilarang. Menurut hukum pidana Islam, semua pelaku zina dapat dikenakan hukuman had karena sudah ditentukan dalam al Quran dan hadist. Bagi pelaku zina yang belum kawin diancam dengan hukuman dera (flogging) dengan tongkat, tangan atau sepatu. Di samping itu, pelaku zina yang sudah kawin diancam dengan hukuman rajam (stoning to death). ${ }^{43}$ Dalam perspektif hukum adat, jika terjadi perzinahan apalagi sampai hamil diluar nikah, maka perempuan yang mengandung dianggap telah melakukan perbuatan yang memalukan dan menjatuhkan martabat pribadi perempuan yang bersangkutan, orangtua dan kerabatnya. Untuk menghilangkan atau menutup malu karena perbuatan zina ini seringkali dilakukan dengan kawin paksa atau kawin darurat. ${ }^{44}$

Salah satu tokoh masyarakat setempat menyatakan bahwa penerapan sanksi bagi pelanggar delik adat di lokasi tempat kejadian pengusiran merupakan upaya para pemuka masyarakat untuk mencegah terulangnya peristiwa yang dapat dikategorikan memalukan. Oleh karena sudah pernah terjadi anggota masyarakat setempat anak perempuannya mengalami hamil sebelum pernikahan dilangsungkan. Apabila dilakukan perlindungan secara preventif bagi perempuan di wilayah tersebut dengan cara memberlakukan adat dalam bertamu di waktu malam hari, diharapkan di wilayah tersebut peristiwa hamil di luar nikah tidak akan terjadi. ${ }^{45}$ Dengan demikian berdasarkan ngelmu titen (ilmu mengingat-ingat) pengalaman yang lalu, masyarakat Sentolo dapat menentukan tindakan preventif untuk menanggulangi hamil di luar pernikahan.

\section{e. Mempertahankan Budaya Aruh- Aruh}

Hidup rukun, saling sapa (aruh-aruh) menjadi hal yang penting dalam rangka hidup berinteraksi dengan masyarakat desa. Bahkan relasi antara satu orang dengan orang lainnya dituntut saling hormat menghormati serta. Oleh karena itu kuatnya tradisi lokal terkait dengan norma pergaulan haruslah diketahui secara baik bagi mereka yang termasuk penduduk asli maupun pendatang. Srawung (berinteraksi) atau kawruh (saling mengenal) dengan sesama tetangga perlu terus dipupuk agar seseorang mampu diterima dengan baik sebagai warga desa setempat. Kondisi berbeda dengan masyarakat kota, dimana satu penduduk dengan lainnya tidak harus saling aruh-aruh (tegur sapa),

\footnotetext{
Ade Saptomo, 2010, Hukum dan Kearifan Lokal Revitalisasi Hukum Adat Nusantara, Gramedia Widiasarana Indonesia, Jakarta, hlm. 100.

Masjfuk Zuhdi, 1997, Masail Fiqhiyah Kapita Selekta Hukum Islam, Gunung Agung, Jakarta, hlm. 35.

Hilman Hadikusuma, 1977, Hukum Perkawinan Adat, Alumni, Bandung, hlm. 145-146.

Hasil wawancara dengan tokoh masyarakat yang bernama Bapak BI pada tanggal 9 Juni 2014.
} 
mengingat masyarakatnya lebih mengarah ke individualisme. Asalkan masing-masing tetangga tidak saling merugikan dianggap cukup baik dalam bermasyarakat. Sebaliknya, jika kehidupan di desa hal tersebut tidak berlaku.

Dalam kaitan budaya tegur sapa atau aruh-aruh yang dijadikan alasan untuk memperkuat dilakukan pemberian sanksi pengusiran bagi pelaku delik adat, dinyatakan beberapa responden sebagai berikut:

Bagi masyarakat di lingkungan terjadinya kasus pengusiran yang beradadiwilayah Sentolo, budaya aruharuh atau tegur sapa antara satu warga masyarakat sama lainnya merupakan adat yang sudah berlangsung secara turun-temurun. Apabila ada warga masyarakat yang melanggar adat tegur sapa ini (delik adat), maka masyarakat akan memberikan reaksi. Dalam hal ini paling tidak warga yang tidak atau enggan melakukan tegur sapa, pasti akan mendapatkan cibiran atau gunjingan dari masyarakat setempat. Pelaku delik adat yang berupa tidur di tempat calon mertua, sebelum diberikan sanksi pengusiran, dia dianggap perilakunya kurang hormat terhadap para pemuda. Karena jika berpapasan dengan warga masyarakat setempat, ketika akan bertamu di rumah calon mertua tidak mau aruharuh. $^{46}$

Koentjaraningrat menyatakan bahwa wujud budaya itu paling tidak ada tiga macam, yaitu: Pertama, berwujud komplek ide, gagasan, nilai dan norma; Kedua, komplek aktivitas kelakuan yang berpola dari manusia dalam masyarakat; dan Ketiga, benda-benda hasil karya manusia. ${ }^{47}$ Apabila dikaitkan dengan kasus di atas, maka budaya tegur sapa tersebut dapat dikategorikan sebagai wujud kelakuan yang diharapkan dikerjakan dalam hidup bermasyarakat. Oleh karena itu, jika ada warga masyarakat atau orang di luar masyarakat setempat tidak melakukan, maka dianggap tidak berbudaya karena itu sama artinya melakukan delik adat.

\section{Kesimpulan}

Pada umumnya lokasi penelitian anggota masyarakatnya sebagian besar beragama Islam sehingga norma agama dalam pergaulan hidup bermasyarakat diupayakan diakomodasi. Masyarakat Sentolo dalam pergaulan antara pemuda dan pemudi cukup sensitif terhadap penyimpangan terhadap ajaran agama. Apabila terdapat anggota masyarakat yang tidak sesuai ajaran agama, maka masyarakat akan memberikan reaksi. Dalam kehidupan masyarakat Sentolo masih sangat menekankan norma kesopanan dalam pergaulannya. Lebih-lebih jika hendak memperisteri warga masyarakat setempat, seharusnya memahami norma kesopanan setempat sehingga tidak akan menimbulkan perbedaan persepsi dalam pergaulan hidup.

Menjalankan adat atau kebiasaan masyarakat yang ideal tidak bertentangan dengan aturan hukum yang tertulis. Hukum tertulis (hukum negara) dalam kehidupan masyarakat hendaknya dijalankan bersama secara beriringan dengan hukum tidak tertulis. Jika terjadi perbedaan antara hukum negara dengan hukum yang tumbuh dalam masyarakat, maka peranan pemuka masyarakat untuk mengharmonisasikan kedua hukum tersebut sangat diperlukan. Dalam pergaulan lelaki dan perempuan pada umumnya jika terjadi sesuatu yang tidak diinginkan seperti hamil di luar nikah, maka pihak yang paling dirugikan adalah pihak perempuan. Oleh karena itu, untuk melindungi perempuan hukum delik adat yang sesuai dengan ajaran agama perlu dipertahankan dalam kehidupan masyarakat.

Dalam kasus pengusiran ini para pemuda juga pernah memberi peringatan kepada pihak keluarga

\footnotetext{
46 Hasil wawancara dengan para pemuda RT setempat yang bernama BA, MW dan ID pada tanggal 9 Juni 2014.

Koentjaraningrat, 1985, Kebudayaan, Mentalitas dan Pembangunan, Gramedia, Jakarta, hlm. 5.
} 
perempuan tentang batasan waktu bertamu. Namun peringatan tersebut tidak dihiraukan dan ketika para pemuda melihat salah satu warga setempat anak perempuannya menerima tamu melewati batas waktu, maka pemuda yang berkumpul di pos ronda berinisiatif menegakan norma yang hidup dalam kehidupan masyarakat. Para pemuda sekitar pukul 01.00 malam, mendatangi rumah pihak perempuan untuk melihat dan meyakinkan adanya tamu seorang lelaki yang menginap di rumah tersebut. Setelah pintu rumah pihak perempuan dibuka, kenyataannya terbukti dan tidak terbantahkan bahwa ada tamu lelaki yang menginap di rumah tersebut.

Saat sudah terbukti secara meyakinkan bahwa ada tamu lelaki yang menginap di rumah perempuan yang sudah melewati batas waktu, maka tamu tersebut diminta keluar rumah dan dibawa ke tempat Bapak RT. Maksud para pemuda membawa ke tempat tersebut adalah untuk diajak musyawarah tentang solusi yang baik terhadap pelanggaran norma kepatutan dalam bertamu di malam hari. Para pemuda dalam musyawarah mengenai masalah ini juga mengundang tokoh masyarakat atau agama dan bapak RT setempat. Dalam hal ini, pihak pelaku pelanggaran dimintai keterangan yang berkaitan tentang asal usul, pekerjaan, status perkawinan, kapan mulai kenal dengan perempuan calon isterinya, alasan tidur di tempat calon mertua dan pemahaman hukum delik adat setempat. Setelah pihak pelaku mengaku tentang pelanggaran yang dilakukan dan adanya saksi dan bukti meyakinkan, maka proses peradilan adat akhirnya diteruskan pada tahap penjatuhan sanksi yang berupa pengusiran.

Sanksi yang diberikan masyarakat kepada pelaku pelanggaran hukum delik adat tidak bertentangan dengan Islam, bahkan dianjurkan untuk mencegah suatu perzinahan. Apalagi tempat kejadiannya tidak jauh dari tempat ibadah (masjid) sehingga pemberian sanksi sudah semestinya diberikan kepada pelaku orang yang mendekati dengan perzinahan. Menurut hukum adat setempat, jika seseorang belum resmi (ijab kabul) menjadi suami isteri itu tidak patut untuk tidur sekamar. Hal ini dikarenakan calon suami isteri yang belum melakukan ijab kabul itu masih dianggap belum sah, sehingga batasan norma kepatutan dalam pergaulan masih berjalan.

Sebelum sanksi dijatuhkan, masyarakat sudah pernah memberi peringatan lisan kepada pihak keluarga perempuan tentang menerima tamu yang tidak semestinya. Namun pihak keluarga perempuan tidak mengindahkan peringatan yang sudah diberikan, sehingga terpaksa masyarakat memberikan reaksi kepada pelaku pelanggaran delik adat. Adapun pemberian sanksi bagi pelanggar delik adat yang dilakukan oleh masyarakat Sentolo tidak dapat dilepaskan dengan adanya pengalaman sebelumnya. Hal ini dikarenakan sebelumnya pernah terjadi hamil di luar nikah, sehingga untuk mencegah perbuatan tersebut, warga yang menerima tamu melewati batas toleransi akan dijatuhi sanksi. Di samping itu, pemberian sanksi juga dikuatkan karena pelaku kurang memperhatikan budaya aruh-aruh (tegur-sapa). Apabila budaya ini tidak dilakukan, maka orang tersebut dianggap kurang menghargai orang lain. Pelaku pelanggaran delik adat ternyata jika berpapasan dengan pemuda setempat seringkali tidak melakukan tegur sapa, sehingga untuk mempertahankan budaya tersebut diperlukan reaksi.

\section{DAFTAR PUSTAKA}

\section{A. Buku}

Ali, Zainuddin, 2006, Sosiologi Hukum, Sinar Grafika, Jakarta.

Ashshofa, Burhan, 2001, Metode Penelitian Hukum, Rineka Cipta, Jakarta.

Bungin, Burhan, 2007, Penelitian Kualitatif
Komunikasi, Ekonomi, Kebijakan Publik, dan Ilmu Sosial lainnya, Prenada Media Group, Jakarta.

Faisal, 2009, Menerobos Positivisme Hukum, Rangkang Education, Yogyakarta.

Hadikusuma, Hilman, 1987, Hukum Kekerabatan 
Adat, Fajar Agung, Jakarta. , 1977, Hukum Perkawinan

Adat, Alumni, Bandung. , 1992, Pengantar Ilmu Hukum

Adat Indonesia, Mandar Maju, Bandung. , 2003, Hukum Waris Adat,

Citra Aditya Bakti, Bandung.

Hiariej, Eddy O.S., 2012, Teori dan Hukum Pembuktian, Erlangga, Surabaya.

Ishaq, 2008, Dasar-Dasar Ilmu Hukum, Sinar Grafika, Jakarta.

Kansil, C.S.T. dan Christine S.T. Kansil, 2007, Pengantar Hukum Indonesia, Sinar Grafika, Jakarta.

Koentjaraningrat, 1985, Kebudayaan, Mentalitas dan Pembangunan, Gramedia, Jakarta.

Mertokusumo, Sudikno, 1982, Hukum Acara Perdata Indonesia, Liberty, Yogyakarta.

Muhammad, Bushar, 1995, Pokok-Pokok Hukum Adat, Pradnya Paramita, Jakarta.

Rato, Dominikus, 2009, Pengantar Hukum Adat, LaksBang Pressindo, Yogyakarta.

Saptomo, Ade, 2010, Hukum dan Kearifan Lokal Revitalisasi Hukum Adat Nusantara,
Gramedia Widiasarana Indonesia, Jakarta.

Soekanto, Soerjono, 1998, Pokok-Pokok Sosiologi Hukum, Raja Grafindo Persada, Jakarta.

Soemitro, Ronny Hanitijo, 1988, Metodologi Penelitian Hukum dan Jurimetri, Ghalia Indonesia, Jakarta.

Van Dijk, R., 2006, Pengantar Hukum Adat Indonesia, Mandar Maju, Bandung.

Zuhdi, Masjfuk, 1997, Masail Fiqhiyah Kapita Selekta Hukum Islam, Toko Gunung Agung, Jakarta.

\section{B. Artikel Internet}

Mahfud M.D., Moh., "Keadilan Subtantif", http://jurnaltoddoppuli.wordpress. com/2014/09/03/keadilan-substantif/, diakses 19 Agustus 2015.

\section{Sumber Lainnya}

Sumardjono, Maria SW, Metodologi Penelitian Ilmu Hukum, Bahan Ajar Tahun 2007, Fakultas Hukum Universitas Gadjah Mada, Yogyakarta. 